\title{
Modelos Transnacionais de Participação Cidadã: o Caso do Orçamento Participativo ${ }^{1}$
}

\author{
YUES SINTOMER", GARSTEN HERZBERG",
}

ANJA RÖCKE*

\section{Resumo}

Este artigo tem dois objetivos fundamentais. Inicialmente, busca apresentar a primeira análise a partir de uma perspectiva transnacional do orçamento participativo, o qual ocupa uma posição central na literatura sobre participação cidadã ou, mais especificamente, sobre inovações democráticas. Em segundo lugar, combina esse amplo projeto empírico com uma abordagem teórica baseada na construção de tipos ideais na tradição weberiana. Nessa perspectiva, apresenta seis modelos de participação cidadã: democracia participativa, democracia de proximidade, modernização participativa, participação de múltiplos atores, desenvolvimento comunitário e neocorporativismo. Embora esses modelos sejam inicialmente concebidos em estreita associação com o orçamento participativo e o contexto Europeu, nosso argumento é que eles podem auxiliar na investigação das dinâmicas, contextos e impactos sociopolíticos e ideológicos do engajamento cívico e da democracia atuais, em escala transnacional.

\footnotetext{
* Professor de Sociologia Política, Departamento de Ciência Política, Universidade de Paris 8 . Vice-diretor do Centro Marc Bloch (Berlim). (Alemanha). E-mail: sy@cmb.hu-berlin.de

** Os autores gostariam de agradecer a contribuição de todos os pesquisadores que fizeram parte da investigação "Orçamentos participativos na Europa", conduzida pelo Centro Marc Bloch, em Berlim, em cooperação com a Universidade Humboldt de Berlin e com recursos da Fundação Hans-Böckler e do CNRS (França) (ver www.buergerhaushalt-europa.de e Sintomer et al., 2012). *** O primeiro critério inclui elementos como a articulação entre mercado, Estado e o Terceiro Setor; o tipo de regime de bem-estar social; a estrutura dos governos locais. O segundo se refere aos objetivos políticos e ideologias implícitas. O terceiro inclui fatos como a influência dos participantes no processo decisório, sua autonomia em relação aos governos locais, a existência de regras de participação. O quarto considera os tipos de atores que participam, a existência de iniciativas a partir das bases (bottom-up), e os impactos sobre a justiça social, a eficiência administrativa, a democracia ou o desenvolvimento sustentável.
}

1 Tradução de Liana V. Fernandes - asapalavra@gmail.com 
Palavras-chave: Orçamento participativo. Participação cidadã. Modelos transnacionais de participação social.

\title{
Transnational Models of Citizen Participation: The Case of Participatory Budgeting
}

\begin{abstract}
This article pursues two main objectives. First, it aims to deliver the first transnational overview and analysis of participatory budgeting, which in the literature on citizen participation or more specifically democratic innovations, occupies a central place. Second, it combines this broad empirical project with a theoretical approach based on the construction of ideal-types in the Weberian tradition. Namely, it presents six models of citizen participation: participatory democracy, proximity democracy, participative modernisation, multi-stakeholder participation, community development and neo-corporatism. Despite these models are initially conceived in close connection with participatory budgeting and the European context, our contention is that they can help to investigate at transnational scale the socio-political and ideological dynamics, contexts and impacts of civic engagement and democracy today.
\end{abstract}

Keywords: Participatory budgeting. Citizen participation. Transnational model of social participation. 


\section{Introdução}

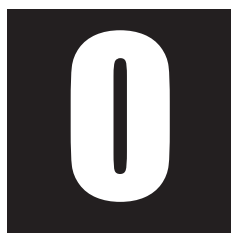

orçamento participativo tem sido um dos mecanismos de participação mais bem sucedidos dos últimos quinze anos e consiste no envolvimento de cidadãos comuns na alocação do gasto público ${ }^{1}$. A propagação global do orçamento participativo, que foi criado em Porto Alegre (Brasil), evidencia muito bem a importância, na atualidade, da participação cidadã na condução de políticas públicas. Dificilmente haverá, nos dias de hoje, uma organização ou entidade territorial disposta a rejeitar - pelo menos no discurso - a ideia de que um maior engajamento cívico seja algo positivo. Nas democracias ocidentais, a participação cidadã é vista como uma potencial cura para o agudo, embora já muito prolongado, "mal-estar" ou "crise" da representação democrática (Tocal e Montero, 2006). Em outras partes do mundo, a participação cidadã é cada vez mais exigida no marco de programas internacionais de desenvolvimento ou, então, é resultado de diversas iniciativas que emergem das bases (bottom-up). Isso levou a uma difusão global de diversos processos participativos, como júris de cidadãos, sondagens deliberativas, fundos de bairros, projetos de desenvolvimento comunitário etc., especialmente a partir dos anos 1990 (Smith, 2009). A propagação global de mecanismos participativos, apesar do grau de influência amplamente variável dos mesmos e da difusão paralela de dinâmicas não democráticas (Crouch 2004), constitui um movimento ainda incipiente, mas cujo desenvolvimento representa

\footnotetext{
1 NTNIMBY - Acrônimo para "not in my backyard" - uma expressão usada para designar a posição de oposição de algumas pessoas a determinados projetos que possam prejudicar seus próprios interesses, ou seja, essas pessoas podem concordar que o projeto seria benéfico para a sociedade ou para determinados grupos, mas não está disposta a abrir mão de suas vantagens em favor da implementação do mesmo.
} 
mais do que uma moda passageira. Os orçamentos participativos podem ser considerados os precursores deste desenvolvimento e, por essa razão, são o ponto de partida da presente análise.

Os modelos que concebemos estudando o orçamento participativo atendem a dois objetivos. Em primeiro lugar, a maioria dos estudos sobre participação cidadã investiga um só, ou um número limitado de casos. Uma série de comparações mais sistemáticas, tanto empíricas como teóricas, foi publicada na última década (Font, 2001; Fung e Wright, 2003; Bacqué et al., 2005; Santos, 2005; Smith, 2009), mas estas se amparam em pesquisas de campo que se utilizam de distintas metodologias e categorias teóricas. O presente artigo resulta de um estudo integrante de um terceiro passo, ainda em curso, da pesquisa sobre participação: conduzimos pesquisas de campo integradas sobre orçamento participativo em mais de 20 cidades europeias, apoiados em uma mesma metodologia e nos mesmos conceitos (Sintomer et al., 2008; 2012a). O trabalho aqui apresentado estende essa metodologia a outras partes do mundo e a casos que foram estudados por outros acadêmicos, para os quais acreditamos ser possível manter a mesma definição de orçamento participativo. Em segundo lugar, a tipologia que propomos é concebida como contribuição ao desenvolvimento de uma tipologia transnacional de participação cidadã. A mesma deve ser aprimorada e modificada ao ser confrontada com outros estudos, mas tem por objetivo propor um tipo de conceitualização que permita agrupar diferentes mecanismos de diferentes partes do mundo. Ela facilita comparações entre países e continentes, bem como uma análise global da participação cidadã e a interpretação dos desenvolvimentos no longo prazo.

$\mathrm{O}$ artigo discute as seguintes questões: (i) que tipos de orçamentos participativos existem atualmente e como podemos explicar suas distintas trajetórias de difusão, suas variadas adaptações locais e sua propagação global? (ii) como essas experiências se associam aos seis diferentes mode- 
los de participação que apresentamos? (iii) quais são as vantagens, desafios e impactos desses modelos globais de participação?

Começaremos por explicar a criação do orçamento participativo em Porto Alegre e, a partir disso, trataremos de sua propagação pela América Latina e outras partes do mundo (Europa, África, Ásia). Na segunda seção, faremos um resumo dos principais argumentos, destacando os principais impactos e desafios relacionados ao processo de orçamento participativo, e apresentaremos seis modelos analíticos de participação cidadã, os quais proporcionam um marco mais global para compreender os desenvolvimentos empíricos da primeira parte.

\section{Orçamento Participativo:}

a difusão transnacional da inovação democrática

O orçamento participativo propagou-se, primeiro, na América Latina, e depois por todo o mundo. Neste processo de propagação, o mecanismo foi hibridizado de formas contrastantes. Portanto, qualquer perspectiva comparativa mundial precisa enfrentar um problema de definição, o que fica ainda mais difícil com um mecanismo cujo rótulo não pode ser controlado por nenhuma organização.

Orçamento participativo: uma definição

Não há ainda uma definição amplamente reconhecida, seja política ou científica, referindo critérios mínimos a serem satisfeitos para configurar um orçamento participativo. Alguns procedimentos estão listados em alguns lugares como consistindo em orçamentos participativos, embora em outros países não fizessem jus a esse rótulo. Por essa razão, é preciso desenvolver uma definição que inclua um conjunto requisitos mínimos, 
de modo a diferenciar inequivocamente esse processo participativo de outros; um que seja, ao mesmo tempo, abrangente o bastante para dar espaço a procedimentos com distintas especificidades. De modo geral, o orçamento participativo permite a participação de cidadãos não eleitos na elaboração e/ou alocação das finanças públicas. Porém, outros cinco critérios precisam ser adicionados para possibilitar uma comparação transnacional (Sintomer et al., 2008, 2012a):

(1) a dimensão financeira e/ou orçamentária deve ser discutida; o orçamento participativo lida com recursos escassos;

(2) o nível municipal deve estar envolvido ou, então, pelo menos, um distrito (descentralizado) com órgão representativo eleito e algum poder na administração pública (o âmbito de bairro não é suficiente);

(3) o processo deve ser recorrente (uma única reunião ou um referendo sobre questões financeiras não são exemplos de orçamento participativo);

(4) o processo deve incluir alguma forma de deliberação pública no âmbito de encontros/fóruns específicos (a abertura de reuniões administrativas ou instâncias representativas clássicas para cidadãos "comuns" não é orçamento participativo);

(5) deve haver algum grau de prestação de contas com relação aos resultados.

Se observarmos o mundo com tais critérios em mente, havia, em 2010, entre 795 e 1.469 orçamentos participativos operando (Sintomer et al., 2010). Este é o resultado de um desenvolvimento muito rápido: dez anos antes, havia menos de uma dezena de experiências de orçamento participativo na Europa; hoje, existem mais de duzentas. Um desenvolvimento semelhante pode ser iminente na Ásia, onde um grande interesse pelo orçamento participativo tem despontado. O número de experiências 
identificado em 2010, na Ásia - entre 40 e 120 - poderá dobrar ou triplicar ao longo dos próximos anos. Isso é o que aconteceu anteriormente na América Latina, o continente com o maior número de orçamentos participativos ao final dos anos 2000 (entre 500 e 920). Na África, novos procedimentos de participação cidadã na formulação de orçamentos públicos também estão em constante desenvolvimento. Portanto, de um ponto de vista global, pode-se observar uma dinâmica considerável.

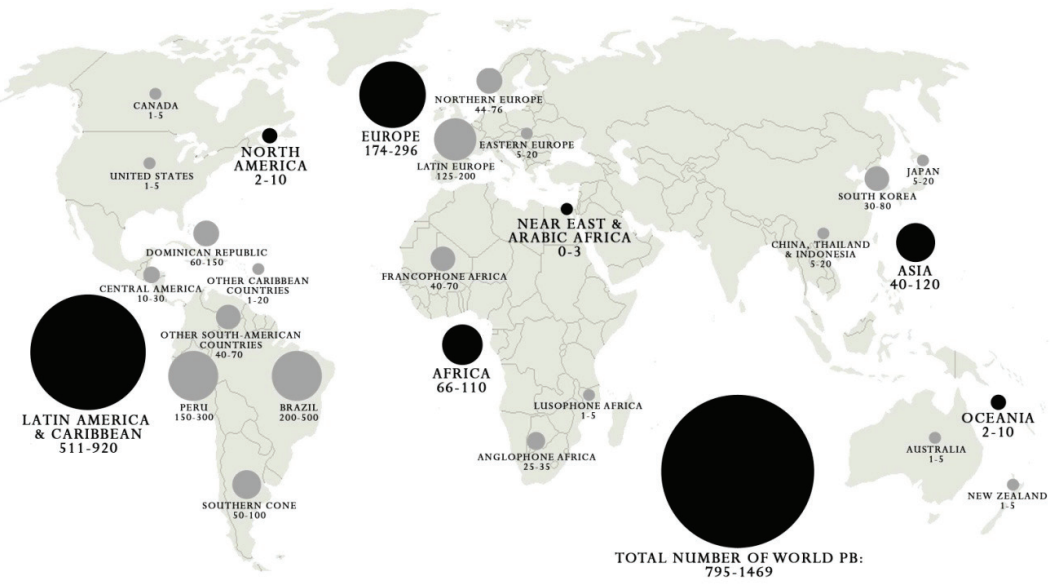

Figura 1. Orçamento participativo no mundo

Fonte: Sintomer et al., 2010 


\section{Porto Alegre: o berço do orçamento participativo}

Quando o orçamento participativo surgiu no Brasil, o contexto era um tanto peculiar. Em um país caracterizado por uma das maiores disparidades de distribuição de renda no mundo, os anos 1980 foram um período em que a transição de uma ditadura para uma democracia atingiu resultados decisivos. Durante quase duas décadas, a imensa mobilização social que sacudiu o Brasil clamava por mudanças políticas e sociais. A nova constituição, adotada em 1988, era bastante progressiva e aberta à participação cidadã, mas o efetivo funcionamento do sistema político continuava caracterizado por corrupção e clientelismo. A cidade de Porto Alegre, que desempenhou um papel crucial na propagação global do orçamento participativo, é também bastante distinta. Porto Alegre (com uma população de 1,4 milhões em 2007), a capital do estado do Rio Grande do Sul, sempre se colocou com reservas ante o governo central. A cidade apresentava um padrão de vida acima da média em relação a outras cidades brasileiras e, por último, mas não menos importante, era um dos lugares onde os movimentos sociais e, especialmente, os movimentos urbanos estavam entre os mais importantes no Brasil (Baierle, 2007; Avritzer, 2002, 2009). A cidade também constituía um dos mais fortes redutos do Partido dos Trabalhadores, o PT.

\section{O processo original}

Após algumas experiências anteriores em cidades menores, o Orçamento Participativo cristalizou-se em Porto Alegre, graças a uma "janela de oportunidade" que se abriu após a vitória eleitoral do Partido dos Trabalhadores, em 1988 (Santos, 1998; Abers, 2000; Fedozzi, 1999, 2000, 2007; Baiocchi, 2005; Avritzer, 2002; Allegretti, 2003; Gret e Sintomer, 2005; 
Baierle, 2007). Não foi apenas o novo governo local de esquerda que impulsionou o processo participativo. A sociedade civil, particularmente as associações comunitárias, também demandou maior poder de participação nas tomadas de decisão. A invenção do OP foi, portanto, o resultado de uma conjunção de processos - iniciativas do topo da administração para as bases (top-down) e outras originadas nas bases em direção à hierarquia administrativa (bottom-up). O processo constituiu uma ação pragmática, e não a aplicação de um projeto político ou intelectual. Em 1993, o OP já havia adquirido as características mais notáveis que ainda tem em Porto Alegre - e, quando o PT perdeu a prefeitura para a oposição, em 2004, após 16 anos no poder, o OP estava integrado de tal forma à vida política da cidade, que o novo governo não ousou abolir o processo.

O mecanismo concebido em Porto Alegre é uma autêntica invenção institucional. A ideia básica é associar o cidadão comum à alocação de dinheiro público, com poder direto de decisão no nível local, poder de codecisão em nível municipal e capacidade de controle em todos os níveis. A pirâmide participativa tem três níveis: assembleias abertas a todas as pessoas nos bairros; assembleias e um conselho participativo de delegados nos distritos; e um conselho geral participativo em nível municipal. Além dos encontros que se organizam em uma base territorial, assembleias temáticas tratam de tópicos específicos (por exemplo, moradia, infraestrutura urbana, serviços de saúde, juventude, cultura, esporte etc.). A meta das assembleias é discutir prioridades e eleger delegados que acompanham o andamento das sugestões apresentadas. Qualquer indivíduo que queira pode participar das reuniões públicas. Associações não têm privilégio, mesmo que tenham um papel decisivo em organizar e mobilizar cidadania. Além disso, elas permanecem independentes do poder executivo municipal, que é seu principal parceiro; o legislativo, apesar de ter poder legal de aprovar ou rejeitar o orçamento municipal, tende a ser marginal nesse mecanismo. 
Os delegados são rigidamente controlados pela base popular. Podem ser destituídos, têm um mandato de um ano e sua reeleição é limitada - aspectos que reduzem muito sua autonomia e os distinguem bastante de representantes eleitos comuns. No nível municipal, o conselho do OP se reúne uma vez por semana, durante duas horas. É dever do conselho assegurar que as prioridades dos distritos sejam atendidas pelo orçamento na maior medida possível. ONGs independentes treinam representantes do orçamento participativo para capacitá-los a planejar em conjunto com a administração. O processo não está limitado a um momento determinado e ocorre em ciclos anuais. Finalmente, além de um controle técnico sobre a viabilidade das obras públicas propostas pelos cidadãos, os fundos que estão à disposição de cada uma das áreas de investimento são distribuídos entre os distritos levando em consideração: (a) a lista local de prioridades atendendo ao princípio de maioria "uma pessoa, um voto", (b) o número de residentes; (c) e a qualidade da infraestrutura ou do serviço disponível, com uma fórmula de alocação que dá mais peso (através de um coeficiente que pode ser revisto ano a ano) para os distritos que têm menos. (Genro e De Souza, 1997; Fedozzi, 2000; Herzberg, 2001; Baiocchi, 2005). A incorporação de um princípio de justiça social em tal critério foi uma das conquistas mais originais da experiência.

Por fim, apesar de ter de enfrentar alguns sérios desafios que, todavia, não foram completamente superados, os resultados gerais foram surpreendentemente positivos. Primeiro, houve aumento da participação ao longo dos anos até 2002, quando esta atingiu o pico de 17.200 pessoas presentes às principais reuniões distritais, e muitas mais no nível de bairros. As características sociais daqueles que participam são ainda mais marcantes: pessoas de baixa renda tendem a se envolver mais que outras; as mulheres, em poucos anos, tornaram-se maioria nas assembléias e pessoas jovens são bastante ativas nas mesmas (Fedozzi, 2007). O orçamento participativo 
proporciona a base àqueles que, antes, sempre foram estranhos ao sistema político. O processo conduziu ao efetivo empoderamento da sociedade civil e, de forma mais notável, da classe trabalhadora (Baierle, 2007). Estruturas clientelistas foram, em grande parte, superadas e as relações entre o sistema político e a sociedade civil melhoraram consideravelmente (Avritzer, 2002). Além disso, o orçamento participativo levou a uma reorientação de investimentos públicos para os distritos menos favorecidos, pelo menos, quando se consideram os investimentos decididos durante o processo participativo (Mororó, 2009): foram instalados serviços básicos de saúde nas regiões mais pobres, o número de escolas e creches aumentou, muitas ruas de favelas foram asfaltadas e a maioria das residências agora tem acesso a água potável e sistema de esgoto. Isso aconteceu, porque quem mais tem investido no processo é a classe trabalhadora e porque o processo contribuiu para uma melhoria dos serviços públicos e da infraestrutura.

Outra questão essencial é que o processo levou a um governo meIhor. A corrupção, que não era muito elevada em Porto Alegre, tornou-se mais difícil. O Orçamento Participativo também foi um incentivo para a reforma da administração pública: uma forte secretaria de planejamento foi criada para debater com o conselho participativo, houve uma maior cooperação entre administrações, foram introduzidos novos métodos orçamentários focados em resultados, e a relação entre técnicos e usuários melhorou (Fedozzi, 1999, 2000). A principal fragilidade naquele nível é que o foco em investimentos anuais tende a transformar a perspectiva de longo prazo em um subproduto: o risco é que decisões tomadas através do OP levem a despesas de longo prazo (manutenção e salários) de difícil sustentabilidade (Banco Mundial, 2008), ou que se torne mais difícil desenvolver outro conceito urbano da cidade (Allegretti, 2003).

Apesar das limitações, Porto Alegre tem sido a mais importante referência transnacional para o orçamento participativo e segue sendo uma 
das experiências mais fascinantes. O processo convenceu ativistas antiglobalização, assim como governos locais e assessores de organismos internacionais, como o Banco Mundial e o PNUD. Para compreender esse sucesso, é preciso, primeiro, observar o resultado do orçamento participativo na América Latina, o primeiro continente por onde o OP se propagou.

\section{Orçamento Participativo na América Latina}

No Brasil, a progressão foi notável, alcançando entre 200 e 250 orçamentos participativos operando em 2001 (Grazia de Grazia e Torres Ribeiro, 2003). O desenvolvimento em grandes cidades foi ainda mais extraordinário: no período de 2001 a 2004, um terço das cidades com mais de 100.000 habitantes e quase $60 \%$ das cidades com mais de um milhão de habitantes estava envolvido; $58 \%$ da população das cidades com um milhão de habitantes ou mais vivia em uma região onde o governo local havia decidido implementar o OP (Marquetti, 2005). Além do Brasil, no início dos anos 2000, esse mecanismo havia seduzido muitas pessoas na América Latina. Dez anos depois, o OP tornou-se um dos mais populares instrumentos de participação cidadã: entre 400 e 900 (de 16.000) cidades da região haviam introduzido o $\mathrm{OP}$, algumas dessas estando entre as mais importantes dessa parte do mundo. Essa disseminação geográfica afetou quase todas as regiões da América Latina.

Os resultados de trinta anos de orçamento participativo na América Latina são importantes, mas apresentam rumos e abrangência variados. Um primeiro efeito é, evidentemente, o fato de que o orçamento participativo é reconhecido por quase todos os atores e observadores. Quando é idealizado e implementado com seriedade, o orçamento participativo aumenta a transparência no uso do dinheiro público e reduz a corrupção (Zamboni, 2007). Um segundo resultado diz respeito ao clientelismo. As 
características do orçamento participativo que ajudam a combater a corrupção também atuam a favor da redução do clientelismo (Avritzer, 2002). Um terceiro desfecho é de importância crucial para a região. Na América Latina, o orçamento participativo é um poderoso instrumento de redistribuição da riqueza em favor dos pobres. Uma série de estudos quantitativos mostrou que bairros pobres tenderam a receber mais investimentos do que bairros mais prósperos (Marquetti et al., 2008; Banco Mundial, 2008). Um quarto resultado, embora observado com menos frequência, é que, quando o orçamento participativo é articulado com um interesse mais amplo na modernização e eficiência das administrações públicas, os dois processos reforçam-se mutuamente (Herzberg, 2001; Gret e Sintomer, 2005).

Em resumo, há um amplo espectro de experiências. Em um extremo, há um polo claramente associado à experiência de Porto Alegre. A "governança participativa empoderada" (Fung e Wright, 2003) é caracterizada pela interação entre uma forte vontade política associada a movimentos de base e uma metodologia que realmente promove a devolução do poder às comunidades locais. Esse "empoderamento" é parte de uma transformação mais ampla e profunda da sociedade e da política e, como consequência disso, as enormes desigualdades que sempre caracterizaram a América Latina têm sido postas em questão (Santos, 2005). Até certo ponto, a invenção e difusão do orçamento participativo podem ser vistas como uma dimensão de um processo mais amplo que sacudiu a América Latina, mudando o continente de ditaduras que implementavam políticas neoliberais a democracias cujos novos governos tentam promover outro tipo de desenvolvimento. No extremo oposto - deixando de lado inúmeras "falsas" experiências - muitos exemplos de orçamento participativo na América Latina constituem essencialmente experiências topdown, isto é, direcionadas dos gestores para as bases, e não fundadas na mobilização da sociedade civil. Envolvem quantias limitadas de dinheiro 
e têm pouco impacto na redistribuição de recursos. Podem, de fato, trazer maior transparência, responsabilidade social e capacidade de resposta às demandas sociais, além de reduzir a corrupção. Associadas a outras "políticas sociais", também podem ajudar a mitigar desigualdades. No entanto, embora possam formalmente ser inspiradas pela metodologia de Porto Alegre, não estão voltadas à participação política e ao empoderamento. O Banco Mundial, que em 2000 concordou em incentivar "políticas para redução da pobreza", está desempenhando um papel significativo na proliferação desse tipo de orçamento participativo. Entre esses dois polos, inúmeros projetos de orçamento participativo são conduzidos por agentes de esquerda ou por ONGs, com propósitos autênticos de mudar o modelo de desenvolvimento, os quais, no entanto, carecem de mobilização de base (bottom-up) ou de uma perspectiva política mais ampla. Nesses casos, projetos de orçamento participativo cristalizaram-se em mera rotina. Alguns atores sociais radicais, fundadores da primeira onda do orçamento participativo, denunciaram tais projetos como exemplos de "orçamento participativo light", que perdeu sua essência (Baierle, 2007).

\section{Orçamento participativo na Europa, África e Ásia}

Na América Latina, os processos de orçamento participativo constituíram, por muito tempo, híbridos do modelo original de Porto Alegre. Isso mudou, quando a ideia de orçamento participativo espalhou-se para outros continentes, primeiro para a Europa, e posteriormente também para a África e Ásia. Quais são as semelhanças e diferenças entre as experiências do orçamento participativo nesses três continentes? Seriam as dinâmicas e resultados que analisamos na América Latina reproduzidas em outros lugares? 
O retorno das Caravelas: Orçamento Participativo na Europa

Na Europa, o contexto difere significativamente daquele da América Latina. Usando uma metáfora, se poderia dizer que as caravelas que levaram os descobridores ao novo mundo no começo da era moderna, retornam agora, portando uma inovação que pode aproximar cidadãos, dirigentes eleitos e servidores públicos. A demanda por uma tal inovação se mostra, certamente, intensa: graus relativamente altos de abstenção eleitoral e de insatisfação com a política estão pressionando os sistemas políticos ocidentais a renovar sua legitimidade e, em muitos países, os governos locais debatem-se com problemas financeiros (Dalton e Wattenberg, 2002). Algumas municipalidades têm respondido a esses multifacetados desafios com o desenvolvimento do orçamento participativo, tendo Porto Alegre como principal referência - embora, muitas vezes, este modelo não seja reconhecível quando se examina o mecanismo na prática (Sintomer et al. 2008; 2012a). O orçamento participativo propagou-se rapidamente pela Europa. Um desenvolvimento impulsionado, principalmente, pelos fóruns sociais mundiais, em Porto Alegre, dos quais participaram ativistas de ONGs, mas também políticos de governos locais de diversos países. Um papel particularmente importante foi desempenhado por aqueles que participaram do Fórum de Autoridades Locais, um evento paralelo ao Fórum Social Mundial. O crescimento foi espantoso. 


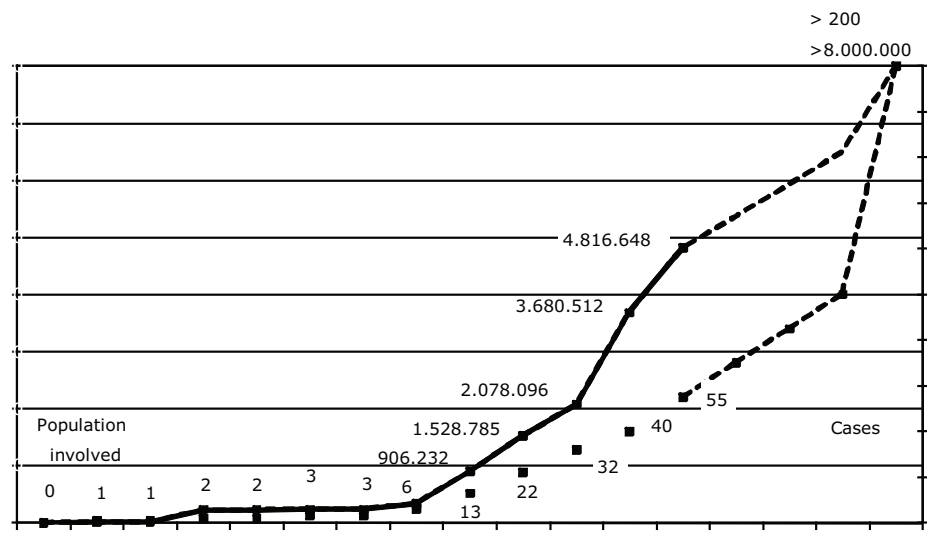

19931994199519961997199819992000200120022003200420052006200720082009

Figura 3. Número de orçamentos participativos na Europa e população envolvida Fonte: Sintomer et al., 2012a

No final da primeira década do novo milênio, embora alguns orçamentos participativos tenham sido descontinuados, a extensão geográfica é tão notável quanto seu crescimento quantitativo. No início da segunda década, o desenvolvimento ulterior provavelmente mais dinâmico pode ser observado no Reino Unido e em Portugal. Em contrapartida, a Itália sofreu um revés significativo. 


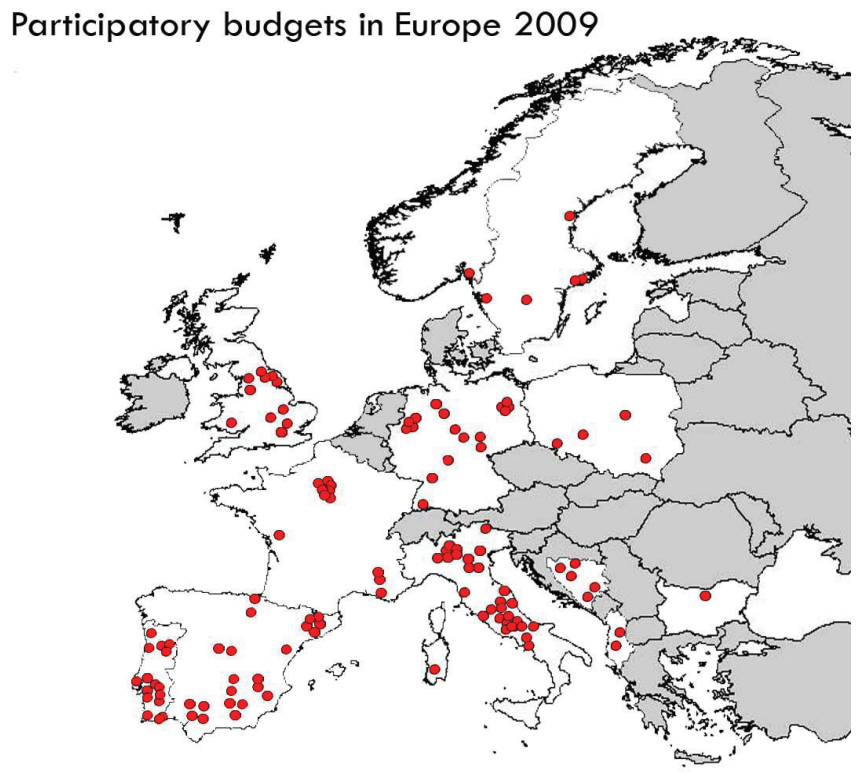

Figura 4. Mapa dos orçamentos participativos na Europa (2010)

Fonte: Sintomer et al., 2012a

As adaptações mais próximas do modelo de Porto Alegre são encontradas principalmente na Espanha e na Itália (Ganuza, 2007). Na península ibérica, são importantes também alguns orçamentos participativos que incorporam associações e grupos organizados. No entanto, as abordagens mais difundidas na Europa são aquelas que fortalecem a comunicação entre, de um lado, administração e políticos e, de outro, cidadãos, todos os quais se encontram nas reuniões de bairro. Exemplos desses modelos podem ser encontrados na França, Itália, Portugal ou Escandinávia. Na Europa Ocidental, inicialmente, eram os partidos de esquerda, socialdemocratas ou pós-comunistas, os mais envolvidos na disseminação do 
orçamento participativo (Sintomer et al., 2012a). Hoje, governos conservadores também estão ativamente envolvidos. Na Alemanha, o orçamento participativo foi, desde o início, um tema suprapartidário (Herzberg, 2009). Na maioria dos países do Norte e Oeste da Europa, diversas redes de governos locais e organizações estatais também apoiam a introdução do orçamento participativo. No Leste da Europa, no entanto, não há um procedimento padrão, e o orçamento participativo é promovido, principalmente, por organizações internacionais, como o Banco Mundial, ONU, USAID, ou GTZ, em cooperação com seus parceiros locais. O orçamento participativo, portanto, vem frequentemente de fora e seu principal objetivo é mobilizar cidadãos e promover a boa governança local. Processos desse tipo geralmente começam com a organização transparente de orçamentos públicos. Em alguns casos, uma estrutura clara do processo de orçamento participativo é apresentada, como ocorre em Svishtov, na Bulgária, ou em Elbasan, na Albania (Shah, 2007; Co-Plan, 2005; 2007). Outra característica comum aos orçamentos participativos nessa região é que a maioria deles envolve projetos piloto com financiamento internacional e são descontinuados quando o apoio é interrompido.

Como na América Latina, pode-se observar um vínculo evidente entre o orçamento participativo e a demanda por maior transparência (Shah, 2007). Isso se aplica tanto à situação do orçamento geral como aos projetos que são discutidos. No entanto, até agora, a transparência não foi suficiente para permitir aos cidadãos controlar efetivamente as finanças da cidade. Apenas em algumas cidades, por exemplo, da Espanha, o orçamento participativo pressiona a administração a relatar seu desempenho na forma de resultados claros, bem como apresentar as atividades administrativas de forma transparente interna e externamente (Ganuza, 2007). De um modo geral, parece perfeitamente plausível que um critério importante para o sucesso do orçamento participativo seja o vínculo entre participação e um processo abrangente de modernização. 
As potenciais consequências políticas são mais contrastantes. Em muitos casos, o orçamento participativo contribuiu para uma melhor comunicação entre cidadãos, administração e a elite política local. No entanto, se o OP poderia de fato desempenhar o papel de intermediação que antes tinham os partidos políticos é uma questão em aberto, e a expectativa geral de que o número de eleitores que vão às urnas aumente com os processos de orçamento participativo não é sustentada pelas pesquisas empíricas. Mas o orçamento participativo pode ter impactos positivos na cultura e habilidades políticas dos participantes. Em todo caso, seu efetivo impacto político na Europa só será possível conhecer em uma perspectiva de médio e longo prazo. Até o momento, a dimensão política é muito menos presente na Europa do que em Porto Alegre.

O contraste com a situação latino-americana é ainda mais acentuado considerando-se a questão da justiça social. A cidade italiana de Grottammare é um dos únicos exemplos de avanços sociais importantes alcançados através do orçamento participativo. Em algumas cidades, no entanto, grupos marginalizados puderam ser mobilizados para o processo como, por exemplo, na cidade espanhola de Albacete. Nesta, o grupo étnico dos sinti e os ciganos, bem como os imigrantes, têm assento permanente no conselho participativo e conseguiram a construção de um centro comunitário que atende às suas necessidades. Para alcançar um maior impacto em termos de justiça social, o processo de orçamento participativo deve incluir a participação de distintos grupos e diferentes estratos sociais (por exemplo, através de procedimentos adequados e de critérios distributivos). Este tem sido o caso, embora em pequena escala, em algumas experiências (Sintomer et al., 2012a) 


\section{África: uma lógica "de doador"?}

Na África, um continente onde as estruturas e culturas democráticas representativas são fracas, alguns movimentos sociais e autoridades locais envolveram-se no processo, mas este permanece altamente dependente da ação de instituições internacionais e de ONGs (Sintomer et al., 2010). Uma reforma tornou-se possível na segunda metade dos anos 1990, quando um conjunto maior de reformas políticas dirigiu a atenção para uma ampla gama de instrumentos de gestão que poderiam servir como pré-requisitos para introdução da democracia participativa (Olowu, 2003). O ritmo lento que caracterizou o enraizamento do orçamento participativo no continente africano deu-se, em parte, em razão do limitado processo de descentralização, visto, inicialmente, como uma premissa necessária a uma inovação que se desenvolveu principalmente em nível local no resto do mundo. Contudo, o encontro entre as primeiras experiências de orçamento participativo e instituições locais, na África, conta uma história não linear: tais experiências são frequentemente "catalisadoras", sustentando e, até mesmo, acelerando a eficácia das reformas descentralizadoras. Essas últimas estariam mescladas com fortes princípios de transparência e receptividade (que em muitos países são declarados em reformas administrativas de nível nacional, geralmente como consequência de pressões originárias de doadores internacionais) e, nos melhores casos, podem também apoiar-se em tradições preexistentes de participação dos cidadãos (Sintomer et al., 2010).

Talvez seja por isso que, na segunda metade dos anos 2000, observou-se uma visível aceleração dessas experiências apoiada por instituições poderosas como o Banco Mundial e as Nações Unidas (especialmente a ONU-HABITAT, com escritório em Nairobi). A existência de uma dose de "neo-colonialismo" na forma como a ideia do orçamento participativo entrou no debate político africano é inegável. Os casos em que os governos 
locais e movimentos de cidadãos tiveram a iniciativa são exceções - podem-se encontrar alguns exemplos, provavelmente, no Senegal. Contudo, a diversidade de atores implicados levou a adaptações locais que são difíceis de classificar. Sobretudo na África anglófona, o orçamento participativo foi integrado a outros mecanismos, cujos objetivos fundamentais são a "desmistificação do processo orçamentário", a "rastreabilidade dos investimentos" e o "planejamento consensual do desenvolvimento" no sentido de envolver a participação dos diferentes segmentos interessados (multistakeholder participation). Seus objetivos cobrem uma multiplicidade de princípios de governança vinculados ao aprimoramento da descentralização e ao alcance dos Objetivos de Desenvolvimento do Milênio definidos pela ONU (UN-Habitat/MDP, 2008). A principal limitação apresentada por essas práticas é o fato de basearem-se na "perspectiva dos doadores", que considera a gestão transparente dos orçamentos um "direito dos doadores" - e está voltada a garantir seus objetivos formais na relação com a comunidade internacional - mais do que um "direito dos cidadãos", o que aumentaria o nível geral de democracia. O caminho temido pelos movimentos radicais latino-americanos é, portanto, o que foi amplamente adotado. Ao mesmo tempo, essa natureza mista dos orçamentos participativos africanos pode desempenhar um papel positivo, abrindo novas possibilidades de estratégias de redução da pobreza e consolidando a descentralização através de novos mecanismos contextualizados. Isso poderia conduzir a novos modelos que concebam a democratização como uma questão substantiva baseada na redistribuição de recursos, no acesso à educação, ao conhecimento e ao poder, e no "direito à cidade".

O Orçamento Participativo na Ásia: entre o desenvolvimento autóctone e trocas internacionais

Na Ásia, o orçamento participativo emergiu ainda depois do que na África, mas experimentou um crescimento importante. Em contraste com 
outros continentes, algumas experiências foram, no início, principalmente autóctones, embora seus princípios e metodologias tenham tido muito em comum com os da América Latina ou da Europa (Liu e Traub-Merz, 2009). Isso ocorre, particularmente, nos casos da experiência de Kerala e do orçamento participativo japonês. Tais processos implicaram um questionamento crítico dos vínculos entre a política, a economia e as reformas administrativas. Essas experiências não tinham efetivamente conhecimento sobre o que se passava em outras cidades e países. Sua metodologia e significado político diferem marcadamente de um lugar para outro, tornando difícil esboçar um quadro geral. Ademais, as estruturas políticas são muito mais heterogêneas na Ásia do que na Europa ou na América Latina, comportando um leque de arranjos que inclui estados federais e centralizados, monarquias constitucionais com governos parlamentares, sistemas presidenciais unitários e estados de partido único. A diversidade de culturas e padrões de vida é marcante. Um fator comum é que o nascimento do orçamento participativo se deu em um período de desenvolvimento econômico acelerado e, em menor grau, em uma fase de descentralização progressiva (UCLG, 2008). Visto como um todo, o processo de orçamento participativo na Ásia tem um pouco de tudo (Raza, 2006).

Os intercâmbios internacionais intensificaram-se, em uma segunda fase, mas não se pode afirmar que contribuirão para unificar o panorama, pois seu impacto difere bastante de um local para outro. O termo "orçamento participativo" começou a ser utilizado apenas por volta de 2005, com referência explícita ao Brasil. A primeira experiência a travar contato direto com os debates europeus ou latino-americanos foi a do estado de Kerala (Índia), que ganhou reconhecimento internacional através de acadêmicos de esquerda (Fung e Wright, 2001; Santos, 2005) e de movimentos altermundialistas, e que foi objeto de extensas discussões durante o Fórum Social Mundial organizado em Mumbai, em 2004. Esta célebre experiência participativa asiática desenvolveu-se em 1996 (Neunecker e 
Mastuti, 2012). A ideia partiu de líderes mais jovens do partido marxista CPI-M. O lançamento do processo foi uma decisão política, mas abriu caminho para um imenso movimento social que deu forma à experiência. Em nenhum outro lugar, exceto algumas regiões da América Latina, o orçamento participativo foi canal para uma mobilização de massa dessa amplitude. A população elegia delegados para acompanharem o processo em cada fase, tendo direito de se manifestarem na definição de prioridades, na implementação e no monitoramento das demandas, elaboradas por consenso, que seriam inseridas em planos de desenvolvimento local e supralocal. Ao longo dos treze anos de sua existência, a "plasticidade" adquirida pelo orçamento participativo de Kerala (Chaudhuri e Heller, 2002) possibilitou a sobrevivência do processo a duas mudanças políticas no governo estadual (Jain, 2005).

Quanto à China, embora esta compartilhe com a Índia algumas características econômicas e sociais, sua estrutura política é completamente diferente, e o interesse crescente no processo de orçamento participativo está inserido principalmente em processos top-down (He, 2012). O conceito foi descoberto em meados dos anos 2000 e um interesse generalizado parece ter despontado após a chamada revolução "Sunshine Finance" (Finanças Transparentes), que promoveu o desenvolvimento da transparência orçamentária com vistas a melhorar o desempenho do governo. Em um país tão grande, a principal dificuldade em identificar exemplos de orçamento participativo em uma perspectiva comparativa é a ambiguidade do conceito chinês de "participação". Em um contexto em que a informação é, muitas vezes, monopólio do poder executivo e dos líderes do Partido Comunista, a noção não necessariamente estará relacionada ao envolvimento direto do povo em políticas públicas. Em vez disso, é muitas vezes usada para designar práticas de diálogo interinstitucional, envolvendo membros do legislativo (os deputados da Assembleia Popular local 
têm sido tradicionalmente excluídos da determinação do orçamento municipal), divulgação de informações, notificações públicas e - na melhor das hipóteses - audiências legislativas, sondagens de opinião, pesquisas e levantamentos (surveys) junto ao público (Sintomer et al., 2012b). Em alguns casos, participação também sugere negociações com organizações como empresas privadas, comitês de moradores ou ONGs. Bem poucas experiências apoiam-se no envolvimento ativo de cidadãos "comuns" e podem ser consideradas orçamentos participativos "genuínos". O meIhor exemplo é, provavelmente, o de Zeguo (He, 2012). A experiência combina a ideia de Porto Alegre, de fazer com que cidadãos decidam a prioridade de investimentos, com assembleias de cidadãos selecionados aleatoriamente (adaptadas da metodologia de sondagem deliberativa inventada por Fishkin, 1998).

A China é importante, não por uma tendência especialmente forte no país de constituir orçamentos de cidadãos, se comparada sob a perspectiva transnacional. É, antes, significativa, porque o partido governante, o PCC, renega o pluralismo político e prefere modernizar a administração do Estado e desenvolver a participação local sob condições autocráticas. O modo de existência do orçamento participativo sob regimes que permitem algumas formas de participação cidadã e excluem outras é particularmente interessante. Como em outras áreas de política social, ao apresentar o orçamento participativo na China, nos deparamos com a qualificação "com características chinesas". De um modo geral, isso significa que o monopólio do poder político pelo PCC é sacrossanto. Reformas administrativas têm prioridade. A nova obrigação das autoridades, de informar ao público seus orçamentos e, por exemplo, tornar essa informação acessível via internet, tem por objetivo melhorar o grau de prestação de contas e reduzir as chances de corrupção. Consultas orçamentárias são voltadas para melhorar a posição da Assembleia Nacional Popular em relação ao Poder Executivo. 
Deputados da Assembleia Nacional Popular, que até então não haviam tido acesso a orçamentos analíticos discriminados e de quem era solicitado apenas aprovar sem questionamento o que fosse enviado do Executivo, podem realizar consultas com cidadãos e especialistas, em projetos pilotos, para melhorar sua competência em planejamento de investimentos. Mais especificamente, com poucas exceções, como a de Zeguo, pode-se chamar esse processo de orçamento público ao invés de orçamento participativo, já que o poder de decisão passa da administração central para aproximar-se da Assembleia Popular, não da população.

No Japão e na Coreia do Sul, dois países ricos que são membros da OCDE, os contextos social, econômico e político não têm muito em comum com os da Índia, e menos ainda com o da China. O orçamento participativo cresceu como ferramenta para lidar com problemas ligados à escassez de recursos, à descentralização incompleta e à falta de prestação de contas e de capacidade de resposta, por parte de instituições eleitas, às necessidades dos cidadãos (particularmente dos pobres). A monarquia constitucional do Japão compartilha uma série de problemas com a Coreia, tais como a grande influência dos partidos nacionais em eleições locais, crescimento da abstenção em eleições locais (menos de 50\%), aumento da corrupção entre servidores públicos e a inflexibilidade das transferências de verbas nacionais para orçamentos locais (UCLG, 2008).

No Japão, os governos locais têm amplas responsabilidades funcionais e respondem por mais da metade do dispêndio público total e por dez por cento do PIB.

Essa forte atribuição formal é combinada ao amplo poder conferido aos cidadãos para requerer referendos locais, melhorias ou extinção de regulamentos, auditorias e, até mesmo, a dissolução da assembleia local, assim como a demissão do prefeito, de membros do conselho ou de servidores públicos. Apesar disso, a participação de cidadãos na formula- 
ção de políticas públicas é pouco frequente, especialmente no campo do planejamento financeiro. A primeira tentativa de envolver a população em questões orçamentárias foi, talvez, o envolvimento ativo de algumas organizações de base que, em 1998, tiveram permissão para legalizar seu status. Depois de 2003, vários processos estavam em andamento, envolvendo cidadãos e organizações comunitárias na discussão de orçamentos públicos. A Coalizão por uma Legislação de Apoio às Organizações de Cidadãos estabelece algumas categorias: transparência nos processos de elaboração orçamentária (por vezes, simplesmente informativa); contestação/discussão por comitês de cidadãos da formulação do orçamento; comunicação do orçamento à comunidade; formulação do orçamento pelos cidadãos; e 1\% dos impostos de habitação entregues a organizações sem fins lucrativos para projetos votados pelos cidadãos. A cidade de Ichikawa se destaca nesta última categoria: lá, o orçamento participativo utiliza $1 \%$ da arrecadação dos impostos de habitação em projetos sem fins lucrativos (Matsubara, 2012). Outras cidades japonesas se inspiraram na experiência de Ichikawa. O termo "orçamento participativo" começa ser de uso comum. Em 2009, Ichikawa organizou uma "cúpula do 1\%", com a intenção de criar uma rede para compartilhar experiências dessa abordagem excepcional de orçamento participativo de desenvolvimento comunitário (Sintomer et al, 2010).

Em Ichikawa, o uso de fundos no orçamento dos cidadãos é determinado pelos contribuintes. Associar o pagamento de impostos à participação traz de volta, em um novo formato, o princípio dirigido aos monarcas europeus, na Idade Média, sob o lema "nada de impostos sem participação", que co-fundou o parlamentarismo com base em qualificação da propriedade. Mas, cabe questionar se o envolvimento em orçamentos de cidadãos deveria estar associado a uma renda tributável ou ao direito de residência. Ichikawa deixou aberta uma via indireta para donas 
de casa, desempregados, universitários e colegiais, os principais grupos excluídos pela qualificação fiscal. Pontos atribuídos a serviços comunitários são distribuídos a quem presta trabalho voluntário na comunidade. Esses pontos, convertidos em vales de valor monetário, permitem a seus portadores votar nos orçamentos de cidadãos. Engajamento social é, dessa forma, tardiamente igualado à tributação.

No final dos anos 2000, a Coreia do Sul foi o país asiático onde o orçamento participativo mais se desenvolveu e, sem dúvida, um dos mais dinâmicos em todo o mundo (Songmin, 2012). A participação cidadã tem uma forte tradição na Coreia do Sul, uma vez que as mobilizações de massa constituíram um fator decisivo na democratização progressiva do país nos anos 1980. Todavia, o desenvolvimento do orçamento participativo está também associado a um marco no qual a dimensão da dívida da administração local e sua capacidade de endividamento estão sob estrito controle do governo central, desde 2000, quando o presidente Rho Moo-hyun enfatizou a participação como meio de produzir "confiança e segurança" nas instituições. Seu mandato (2003-2008) foi rotulado como "Governo Participativo" e contribuiu muito para a rápida expansão do orçamento participativo no país. O conceito foi introduzido como um processo que parte das bases (bottom-up), mas sua difusão foi estimulada de forma descendente (top-down) pelo governo nacional. Um dos exemplos mais marcantes é Dong-ku (Songmin, 2012). Os princípios chave do orçamento participativo na Coreia foram importados do Brasil, mas foram adaptados localmente, dando origem a uma "versão reduzida" do modelo de Porto Alegre. A esta versão, falta a mobilização social que caracteriza a cidade brasileira. O orçamento participativo é um processo de decisão conjunta, do qual todos os cidadãos comuns podem participar fazendo propostas em um primeiro estágio, enquanto grupos de delegados acompanham os passos seguintes. O processo consiste de reuniões 
locais, das quais todos os residentes da região podem participar, e de uma assembleia municipal que confere um papel crucial a um comitê de cidadãos no orçamento participativo (subdividido em cinco fóruns temáticos). Este comitê é eleito, em parte, por meio de candidaturas abertas e, em parte, através de indicações feitas por organizações comunitárias. Todos os membros são treinados para suas funções na denominada "escola do orçamento participativo". A replicação coreana dos orçamentos participativos e a adoção de estatutos não promoveram a homogeneidade. Contudo, algumas ferramentas (como sondagens, licitações, fóruns e boletins informativos na internet, audiências públicas e seminários) têm sido oferecidos para promover processos não exclusivos a todos os cidadãos, em cada fase, e a tradição das Escolas do Orçamento de Cidadãos e dos Seminários de Política Orçamentária é uma das contribuições mais importantes da Coreia do Sul ao resto do mundo nesse campo.

\section{Seis modelos de participação cidadã}

De que forma esses tão diversos desdobramentos e adaptações do processo brasileiro podem ser integrados em um modelo sistêmico? Como se poderia extrapolar o caso específico do orçamento participativo para apresentar uma análise mais geral da participação cidadã?

\section{Um panorama descritivo}

A partir do panorama que esboçamos, fica evidente que não há, em nenhum continente, um modelo uniforme ao qual se poderia comparar os outros. De um modo geral, um panorama descritivo pode identificar três distintas tendências. No nível mais alto, temos orçamentos participativos que visam a uma mudança essencial das condições vigentes, a ser alcançada como um passo de um movimento mais amplo por renovação. 
Esses são baseados na interação entre governos e movimentos de base. Esses processos orçamentários são voltados à superação das injustiças sociais e à conquista do desenvolvimento sustentável. Isso significa romper com práticas estabelecidas de patronagem e de corrupção. Quando a sociedade civil se mobiliza, a pressão que ela exerce contribui para alcançar esse objetivo. Há vários casos desse tipo de desenvolvimento no Brasil e na América Latina. Por muito tempo a experiência de Porto Alegre se manteve como um desses exemplos, e esse se reproduziu, na América Latina, uma centena de vezes. Todavia, os resultados do orçamento participativo na Europa e na África são muito mais frágeis e ainda não se observou, nesses continentes, um caso comparável ao de Porto Alegre. Na Ásia, Kerala, onde o modelo de Porto Alegre foi combinado com desenvolvimento rural, é um dos poucos exemplos de uma ampla mudança social.

A segunda tendência envolve o uso do orçamento participativo para fazer avançar uma pauta de reformas. Embora não envolva uma ruptura com práticas antigas - e os objetivos permaneçam os mesmos - este tipo de orçamento participativo causa, sim, um impacto. O governo local é o principal ator nesse caso, mas os cidadãos não estão ausentes. Há pelo menos algumas regras claras, ou uma rotina, as quais permitem que práticas estabelecidas tornem-se regras. Os objetivos variam largamente. $\mathrm{Na}$ maioria dos continentes, o orçamento participativo está vinculado à modernização administrativa. Em muitos casos, ele é idealizado para aprofundar os processos de descentralização e transformar a nova autonomia das municipalidades em realidade concreta para os cidadãos. O mesmo se aplica ao impacto social, que nem sempre precisa ser inovador. Frequentemente, o objetivo é melhorar as vidas de grupos em desvantagem social, preservando, ao mesmo tempo, a estrutura básica do sistema e os padrões vigentes de alocação. Contudo, o maior impacto da reforma envolve uma melhoria nas relações entre governos locais e seus cidadãos. 
Embora impactos além desse não sejam, em geral, muito evidentes, governos locais mostraram-se abertos e dispostos a implementar sugestões apresentadas por cidadãos, o que pode ser visto como uma medida para construir segurança e induzir confiança. No sul do planeta e no leste europeu, esse tipo de orçamento participativo tem frequentemente o apoio de organizações internacionais.

Alguns orçamentos participativos dessa segunda tendência mostram traços de uma terceira, na qual o orçamento participativo tem, em grande parte, natureza simbólica e, na qual, entre o objetivo proclamado e a realidade existe um abismo. Nesse caso, o objetivo já não é, de fato, consultar os cidadãos. Reuniões são utilizadas para legitimar o caminho que já foi tomado, e os responsáveis não têm mais intenção de mudar. Em alguns casos, as sugestões de cidadãos a respeito da formulação de um pacote de medidas austeras não são suficientemente analisadas, e nenhum meio é disponibilizado para facilitar a aquisição de conhecimentos técnicos pelos cidadãos. Orçamentos participativos simbólicos são encontrados tanto em democracias estabelecidas como em regimes autoritários. No último caso, a intenção é exibir uma aparente abertura que, na realidade, não existe; a participação é idealizada para apaziguar a população e/ou financiadores internacionais.

\section{Seis modelos conceituais}

No entanto, esse balanço ainda é esquemático demais para efetivamente captar a imensa complexidade do orçamento participativo no mundo - sem falar de outros mecanismos de participação. Por essa razão, pode ser útil incluir uma outra tipologia, mais conceitual e de maior complexidade. Como exposto na introdução, propomos uma abordagem weberiana visando desenvolver modelos de tipos ideais. Tipos ideais nem sempre coincidem completamente com os dados empíricos, mas permi- 
tem classificar e sistematizar a intrincada variedade de casos reais. Eles constituem um mapa conceitual sobre o qual se podem situar casos empíricos. Deve-se sempre combinar vários modelos para poder explicar um caso específico - como em um mapa rodoviário, geralmente não se viaja precisamente em direção ao Norte, Sul, Leste ou Oeste, mas a existência dos pontos cardinais nos ajuda a não perder o rumo. Esse tipo de tipologia está relacionado às discussões sobre os modelos do bem-estar social que têm se desenvolvido há algumas décadas (Esping-Andersen, 1990). Nossos modelos estão construídos com base em diferenças associadas a quatro critérios: contexto sociopolítico e econômico, estruturas políticas de ação coletiva, tipo de procedimentos e de mecanismos participativos, dinâmicas de ação coletiva. Os critérios também consideram a relação entre política convencional e processos participativos, e as vantagens, desvantagens e desafios dos modelos participativos. Propomos distinguir entre seis modelos de participação.

\section{Democracia participativa}

Decidimos denominar o primeiro modelo de "democracia participativa". Sua principal característica é o surgimento simultâneo de um "quarto poder" (participantes têm um efetivo poder decisório, distinto daqueles do judiciário, do legislativo e do executivo) e de um "poder compensatório" (a mobilização autônoma da sociedade civil dentro do processo leva ao empoderamento das pessoas e à promoção de formas cooperativas de resolução de conflitos). Nesse modelo, a participação tem repercussões reais em termos de justiça social e de relações entre a sociedade civil e o sistema político. Esse modelo implica a participação da classe trabalhadora ou dos grupos vulnerabilizados e não apenas das classes médias, bem como o surgimento de uma esfera pública "plebéia". Isso produz uma equação positiva entre política convencional e não convencional, uma 
vez que as dinâmicas de ambas podem combinar-se. Governos locais são ativos na inauguração dos processos, mas também na implementação de decisões. Em tal modelo, a participação cidadã é uma bandeira de esquerda e é concebida como alternativa ao neoliberalismo e como parte de uma reforma social e política. Ao mesmo tempo, a modernização da ação administrativa não é a ideia central. O termo "democracia participativa" é, com frequência, usado como um lema. Preferimos defini-lo de um modo mais preciso: ele implica que os mecanismos tradicionais de governo representativo estão vinculados a procedimentos democráticos diretos, nos quais habitantes não eleitos (e seus delegados investidos de um "mandato semi-imperativo") têm de fato poder de decisão, embora, legalmente, a decisão política permaneça nas mãos dos representantes eleitos. Por isso acreditamos que o termo designa bem o primeiro modelo.

Alguns orçamentos participativos latino-americanos podem ser, em boa parte, analisados de acordo com esse modelo. Na Europa e na Ásia, algumas experiências importantes, como em Sevilha (Espanha) ou em Dong-ku (Coreia do Sul), compartilham de suas características, embora representem uma versão "light" do modelo. Kerala se enquadra nele, até certo ponto, mas compartilha algumas dimensões que remetem mais ao modelo de desenvolvimento comunitário. No que se refere à África, esse modelo não contribui muito para a compreensão do orçamento participativo. Esse modelo é interessante, também, para compreender uma série de processos de participação cidadã na Bolívia, Equador e, em menor grau, na Venezuela.

Pode-se argumentar que, das perspectivas política e filosófica, esse modelo é o mais estimulante, por combinar uma forte participação com impactos sobre a justiça social. Contudo, análises históricas e sociológicas demonstram que ele funciona apenas sob circunstâncias específicas e que, portanto, em determinados contextos, outros modelos são mais adequados. Cada modelo apresenta suas próprias vantagens e desvantagens, que 
somente podem ser avaliadas no terreno. A desvantagem do modelo de democracia participativa é que ele requer muitos fatores favoráveis (particularmente uma forte vontade política e uma sociedade civil mobilizada e independente, disposta a cooperar com governos locais). O modelo é instável, se confinado apenas ao nível local. Os principais desafios incluem: como unir de modo eficaz participação e modernização do Estado, e como evitar o risco de cooptação de membros mobilizados da sociedade civil pela estrutura institucional (o que os isolaria de suas bases).

Certamente, alguns observadores e atores poderiam insistir em que a modernização administrativa ou o envolvimento das empresas é mais importante do que conferir aos cidadãos poder direto de decisão, ou que o governo representativo deve manter o monopólio da tomada de decisões, limitando-se a participação ao processo consultivo. Acreditamos que mesmo quem partilha dessa opinião pode, ainda assim, aceitar o valor descritivo desse modelo.

\section{Democracia de proximidade}

A característica chave do segundo modelo é que ele compreende proximidade em seu duplo sentido - de contiguidade geográfica e de maior comunicação entre cidadãos, gestores públicos e autoridades locais. Governos locais têm algum poder real, mas os gestores públicos não estão necessariamente envolvidos em um forte processo de modernização. A democracia de proximidade é baseada em "escuta seletiva": sua lógica é a de que quem tem o poder de decisão escolhe a dedo as ideias dos cidadãos. A democracia de proximidade é baseada em regras informais e confere à sociedade civil autonomia meramente marginal. Além de retórica ideológica, ela constitui mais uma atividade deliberativa do governo representativo do que uma incursão a uma nova forma de democracia. Embora governos locais de esquerda tendam mais facilmente a 
comprometer-se com a democracia de proximidade do que os de direita, não há uma divisão clara. A democracia de proximidade não é um instrumento de justiça social, mesmo que garanta algum grau de solidariedade (por exemplo, limitando a especulação imobiliária ou introduzindo políticas de renovação urbana). Como o processo é meramente consultivo e a sociedade civil não tem muita independência, a possibilidade de um quarto poder ou de um equilíbrio cooperativo parece estar excluída. A democracia de proximidade é essencialmente descendente (top-down). Esse modelo geralmente envolve cidadãos voluntários, individualmente, embora as ONGs desempenhem um importante papel não oficial e alguns de seus instrumentos de participação utilizem seleção aleatória para escolher cidadãos. Seria difícil para a democracia de proximidade gerar qualquer remobilização no contexto da política convencional, exceto no nível micro-local, pois ela lida essencialmente com "coisas pequenas".

A democracia de proximidade é indubitavelmente o modelo mais difundido na Europa, e é sustentada por fundos comunitários e conselhos de bairro. O mesmo se pode dizer da América do Norte, Austrália, Coreia ou Japão. No velho continente, alguns orçamentos participativos também se enquadram nesse modelo. Nos países do sul do planeta, esse modelo é também bastante difundido, embora casos mais concretos sejam, provavelmente, experiências "mistas" que combinam características deste e de outros modelos. Poderíamos, inclusive, interpretar a "sunshine finance revolution" (revolução das finanças transparentes), na China, à luz desse modelo.

O modelo da "democracia de proximidade" é caracterizado por um baixo nível de envolvimento político e um baixo nível de mobilização (particularmente da classe trabalhadora). Sua principal vantagem é meIhorar a comunicação entre cidadãos e formuladores de políticas. Suas desvantagens estão na forma essencialmente arbitrária, pela qual os políticos "ouvem seletivamente", e escolhem a dedo, as perspectivas da po- 
pulação; no fato de que isso conduz a perspectivas NIMBYNT (não no meu quintal); e na cooptação da sociedade civil por instituições existentes. $\mathrm{O}$ desafio que o modelo enfrenta é, especialmente, o de assegurar que a participação seja, de fato, associada à tomada de decisões, de modo a aprimorar efetivamente a qualidade da prestação dos serviços e do funcionamento da administração pública; e, ainda, o de combinar proximidade com modernização do Estado, transcendendo o âmbito do bairro.

Modernização participativa

A característica chave do terceiro modelo é que a participação é geralmente um aspecto das novas estratégias de gestão, num contexto em que o estado está tentando se modernizar para tornar-se mais eficiente e legítimo - e, em alguns casos, para resistir a pressões por privatização. Visto por esse ângulo, o processo participativo é descendente (top-down), não é político e tem valor apenas consultivo. A independência da sociedade civil é limitada e não há espaço para um contra-poder. O que está em jogo, nesse caso, é outro aspecto: a participação é associada, principalmente, à boa gestão e visa aumentar a legitimidade de políticas públicas. A política permanece nos bastidores, de modo que os usuários ou clientes dos serviços públicos são objetos de interesse, mais do que cidadãos. A população envolvida é essencialmente de classe média, exceto quando se utilizam procedimentos específicos para melhorar a diversidade social dos participantes. Os marcos normativos em que se baseia esse modelo se aproximam mais das versões participativas da Nova Gestão Pública do que da utopia da democracia participativa como alternativa à globalização neoliberal.

No que diz respeito ao orçamento participativo, esse modelo tem influência na Alemanha e, em menor grau, no norte da Europa. Ele é amplamente difundido no caso de outros mecanismos participativos propostos por estratégias da Nova Gestão Pública (estatutos de usuários, co- 
missões de usuários, pesquisas de satisfação, linhas diretas e assim por diante). Os conselhos de bairro e administrações de bairro, em geral, podem ser enquadrados nessa perspectiva. Esse pode também ser o caso em algumas cidades com administração pública modernizada ou mesmo em contextos liberais, em que alguns governos locais querem impulsionar a eficiência de sua administração pública. Autoridades municipais das mais diversas correntes políticas introduziram processos de orçamento participativo que, em maior ou menor grau, estão associados a esse modelo. Por exemplo, as experiências na China, que tentam integrar cidadãos comuns - como é o caso de Zegou - podem ser interpretadas no contexto de modernização participativa: elas podem contribuir para melhorar serviços públicos. O transporte público de Xangai já instituiu um elaborado processo de participação do consumidor (Rong Hu, 2009). Experiências africanas também partilham de algumas características da abordagem da modernização. Isso ocorre, particularmente, quando o orçamento participativo está vinculado a processos de descentralização.

Essa diversidade é fortalecida pelo fato de que a modernização participativa pode aproveitar-se de uma ampla gama de projetos e abordagens participativas, variando de mecanismos que permitem comentários dos usuários, a certificados de qualidade ou conselhos que envolvem os usuários na gestão dos serviços ou instituições locais. Assim, as abordagens que se aproximam do tipo ideal da modernização participativa desenvolveramse em diversos contextos, particularmente, no norte da Europa.

A vantagem desse terceiro modelo é o vínculo estreito entre modernização da gestão pública e participação, além do fato de que um consenso suprapartidário pode ser alcançado com facilidade. O avesso disso é que há um baixo grau de politização, o que dificulta a introdução de questões mais amplas, particularmente a da justiça social; processos que se aproximam desse modelo tendem a ter natureza puramente adminis- 
trativa. Os desafios implicados incluem: como aumentar a participação e autonomia da sociedade civil e desenvolver uma dimensão política genuína (ao invés de se tornar um processo meramente tecnocrático), de modo a possibilitar uma política com ímpeto renovado.

Participação de múltiplos atores

A principal característica do quarto modelo é que os cidadãos que participam constituem apenas um entre múltiplos atores, que incluem empresas privadas e governo local. Nesse modelo, a política local tem espaço de manobra limitado frente às forças econômicas, e são os doadores que mandam. A abordagem não é muito politizada e as principais questões de desenvolvimento da política local só podem ser discutidas de forma periférica. Embora os processos participativos possam envolver algum poder de decisão, eles estão amarrados a uma abordagem descendente (top-down), que não possibilita a emergência de um poder compensatório cooperativo.

Ao invés de um quarto poder emergente, instrumentos participativos desse tipo representam uma expansão dos mecanismos de governança (através dos quais, interesses econômicos privados ganham influência institucional no processo decisório). Na parceira participativa públicoprivada, a sociedade civil é fraca e tem pouca autonomia, mesmo que as regras do processo decisório sejam claramente definidas. Quem participa são, essencialmente, cidadãos de classe média e os projetos são voltados a cidadãos ativos ou a ONGs, todos os quais se pretendem porta-vozes dos moradores locais. Organizações internacionais como o Banco Mundial, as Nações Unidas ou organizações de apoio ao desenvolvimento, sediadas nos países ocidentais, desempenham um papel importante na disseminação desse modelo. Nele, a participação está, frequentemente, a serviço de políticas que incorporaram as limitações da globalização neoliberal: 
na melhor das hipóteses, ela representa apenas um pequeno peso para contrapor essas forças. Por esse motivo, o modelo parece diametralmente oposto ao de Porto Alegre. O marco normativo dominante é um híbrido da retórica de governança e do tema da participação cidadã.

No que diz respeito a orçamentos participativos, este modelo existe no leste europeu e apoia-se, particularmente, na abordagem de participação de múltiplos atores. Em relação a outros mecanismos participativos, o modelo tem influência considerável no mundo anglo-saxônico e além, particularmente em países onde o estado tem pouca força. Os orçamentos participativos da África, impulsionados por doadores, partilham algumas características deste modelo.

Prefeituras de diversas tendências políticas introduziram processos influenciados por este modelo. Sua vantagem é adaptar-se bem a contextos onde o mercado é forte e direcionar financiamento privado a projetos de interesse geral. O "modelo de múltiplos atores" também inclui empresas privadas, que são fundamentais para o desenvolvimento local, mas que em outros tipos ideais tendem a ficar de fora do processo participativo. No entanto, o custo disto é que empresas privadas têm supremacia em um processo onde se envolveram voluntariamente (e sob a condição explícita de lucrar com seu envolvimento), enquanto a sociedade civil fica limitada a um papel subordinado e não pode questionar a estrutura econômica e política dominantes. Os desafios diante desse modelo são os de como associar instrumentos participativos ao interesse central de políticas municipais, isto é: estabilizar os fluxos financeiros de que dependem (estes fluxos são precários e não operam sob limites legais claros); equilibrar o peso dos diversos atores envolvidos no processo e dar abertura a tópicos que Ihes sejam relevantes; e, contrapor a pressão para transformar ONGs e associações em organizações quase-governamentais ou em entidades semicomerciais. 


\section{Desenvolvimento comunitário}

A característica dominante do quinto modelo é que a participação está voltada fundamentalmente à fase de implementação de projeto, num contexto que desvincula a política municipal de um forte processo participativo conduzido tanto por uma dinâmica ascendente quanto uma descendente. As margens para política representativa são bastante pequenas neste modelo ideal. O novo poder emergente, portanto, não está estreitamente vinculado a instituições locais - um aspecto que distingue o desenvolvimento comunitário do modelo de "democracia participativa". A influência de Porto Alegre é mais indireta, pois se fundiu com tradições locais mais antigas. Há regras de procedimento bastante claras e uma relativamente alta qualidade de deliberação. Os participantes mais ativos são aqueles envolvidos na coordenação de associações comunitárias: na Europa, nos EUA ou na Inglaterra, as frações superiores das classes trabalhadora e média; nos países do sul, os participantes podem vir das classes mais baixas. O papel das ONGs é frequentemente decisivo, com a participação sendo voltada a grupos vulnerabilizados ou marginalizados, com vistas a ações inclusivas, ao invés de uma forma ampla de justiça distributiva. Em uma configuração como esta, é provável que a participação não convencional, vinculada a atividades comunitárias, venha a substituir em parte a participação convencional (filiação a partidos e votação em eleições).

No campo do orçamento participativo, esse modelo se desenvolveu principalmente no mundo anglo-saxônico (Grã-Bretanha, Canadá, na cidade Guelph) e em muitos países do sul do planeta. Outras formas de desenvolvimento comunitário difundiram-se em alguns lugares, e são provavelmente o tipo mais frequente de participação cidadã em escala mundial. A inclinação política do governo local não é um fator decisivo. $\mathrm{O}$ desenvolvimento comunitário está referido a várias estruturas normativas: experiências de tendência radical defendem o empoderamento, assim 
como as liberal-socialistas, as do liberalismo de esquerda e, às vezes, as tradicionais de comunidades locais, particularmente as indígenas; outras experiências falam de capacitação ou entendem o empoderamento de forma menos radical, destacando as capacidades individuais, ao invés das relações coletivas de poder.

Esse modelo participativo apresenta vantagens evidentes em um contexto em que o governo local é fraco e onde, de modo oposto, a sociedade civil tem efetiva independência e tradição de organização as quais possibilitam ao setor comunitário gerir projetos locais. A desvantagem reside no fato de ser difícil construir uma visão geral da cidade e, ainda mais, de uma sociedade justa, bem como nos vínculos tênues entre participação, modernização da gestão pública e política institucional. Os desafios que o modelo enfrenta incluem tentar manter a gestão de organizações comunitárias livre de influências administrativas e evitar que se tornem órgãos quase públicos; além disso, processos desse tipo precisam ver além do nível micro-local e contribuir com a transformação da política institucional.

Neo-corporativismo

O traço distintivo do modelo "neo-corporativista" - que é provavelmente o modelo mais antigo de participação, se observarmos a era pós-Segunda Guerra - é que o governo local desempenha um importante papel, ao cercar-se de grupos organizados (ONGs, sindicatos e associações de empregados), grupos sociais (idosos, grupos de imigrantes, etc.) e de diversas instituições locais. Neste modelo, o governo visa a estabelecer um amplo processo de consulta com "quem importa" e procura chegar a um consenso social através da mediação de interesses, valores e demandas por reconhecimento de diversos segmentos da sociedade. Países onde os governos estaduais e locais são fracos, aparentemente, não seriam muito receptivos ao modelo neo-corporativista, devido à sua pouca 
flexibilidade. Neste modelo, as inclinações políticas dos governos locais variam, assim como as dinâmicas de modernização da gestão pública. Os marcos normativos estão vinculados ao neo-corporativismo e a certas variações do conceito de governança.

No modelo "neo-corporativista", as regras de participação podem ser formalizadas, ao passo que a qualidade do debate é variável. Na maioria dos casos, processos corporativistas locais são fundamentalmente consultivos. Embora as organizações da sociedade civil desempenhem um papel importante nesse modelo, sua autonomia de ação varia, dependendo do contexto. Na Europa, em nível local, a presença do modelo é bastante limitada e as experiências neo-corporativistas são processos essencialmente descendentes. Por essa razão, o surgimento de um contra-poder é improvável. O resultado é mais um caso de reforço do modo tradicional de participação do que um ciclo virtuoso de participação convencional e não convencional (ou da substituição da primeira pela última). No nível nacional, os mecanismos neo-corporativistas clássicos, especialmente aqueles utilizados para administrar serviços de saúde ou de previdência social, operam, em geral, de formas bastante distintas: podem ser extremamente formalizados, incluir verdadeira autoridade decisória e conferir poder de decisão aos parceiros sociais.

Em termos dos processos de orçamento participativo, o modelo "neocorporativista" tem forte influência sobre as Agendas 21 locais e sobre planos estratégicos participativos, formas conhecidas e importantes de participação em nível local. Esse não é um modelo comum nos orçamentos participativos europeus. Ele tem tido certa influência apenas na Espanha, onde a combinação com a abordagem de Porto Alegre deu origem a formas de democracia associativa. No entanto, o reforço dos mecanismos de participação da sociedade civil no funcionamento de diversas gestões públicas municipais pode levar ao desenvolvimento de formas originais de orçamen- 
to participativo. No âmbito internacional, pode-se interpretar a atuação de diversos tipos de atores (governos nacionais, ONGs, universidades, empresas, etc.) nas Conferências Mundiais dos anos 1990 à luz desse tipo ideal.

As organizações internacionais desempenham um importante papel na disseminação desse modelo. Sua principal vantagem é a integração entre as principais estruturas organizadas da sociedade, o que facilita um consenso social em torno de certos aspectos de políticas públicas. No entanto, ele é caracterizado por relações assimétricas de poder e os cidadãos não organizados são excluídos. No nível local, os principais desafios são: integrar participação e modernização, evitar a cooptação de associações ou ONGs (que podem se afastar de suas origens) para a gestão pública, e ultrapassar uma simples abordagem seletiva e efetivamente discutir as questões mais controversas.

\section{Conclusão}

Neste artigo, mostramos que o orçamento participativo se disseminou pelos continentes em distintas modalidades, tendo ocorrido uma complexa mistura de transferências, adaptações e inovações autóctones. Assim como Esping-Andersen (1990) observou que a ideia do bem-estar social assumiu diferentes formas, revelamos que o modelo inventado em Porto Alegre emergiu como diversos modelos ao longo de seu trajeto ao redor do mundo. Isso se aplica ao processo de trocas entre América Latina e Europa, mas também à África e, mais ainda, à Ásia, onde experiências originais estão em curso com o desenvolvimento participativo de Kerala, o OP de sondagem deliberativa da China, os orçamentos dos contribuintes, no Japão, ou as versões sul-coreanas do modelo original de Porto Alegre. Parece claro que não há um télos único ao qual os orçamentos participativos do mundo se direcionem. Por um lado, um processo passível de ser combinado com certas tradições de participação vigentes pode 
trazer mais resultados do que um processo "artificial", sem vínculos com estruturas existentes. Por outro lado, inovações radicais parecem ser necessárias para pôr em questão as atuais relações de poder assimétricas expressas nos mecanismos participativos mais comuns e na sociedade. Este não é um dilema fácil de resolver, e esta é uma das razões da existência de múltiplos caminhos, ao invés de uma "estrada real", para um desenvolvimento urbano mais justo e mais democrático no mundo; caminhos que se adéquam a cada situação.

Os seis modelos propostos (democracia participativa, democracia de proximidade, modernização participativa, participação de múltiplos atores, desenvolvimento comunitário e neo-corporativismo) revelam diferenças marcantes, muito influenciadas pelas tradições políticas de participação e de democracia existentes. O orçamento participativo é apenas um exemplo importante de uma propagação mais ampla de inovações democráticas. Esta é uma das razões para não limitarmos nossa tipologia ao OP. Pode ser proveitoso construir modelos que transcendam as descrições empíricas, e, especialmente, que não enfoquem apenas nos instrumentos de participação cidadã, mas levem em conta fatores como contexto sociopolítico e econômico, as estruturas políticas, as dinâmicas de ação coletiva e os resultados da participação, ou a relação entre política convencional e os processos participativos. Nosso trabalho terá sido bem sucedido, se outras pesquisas fizerem uso - e, provavelmente, modificarem - essa tipologia, para melhor compreender outros mecanismos participativos. Seria de especial interesse explorar como outros mecanismos se relacionam com as características do orçamento participativo que descobrimos em diferentes partes do mundo.

Uma mera dicotomia (tal como autêntico x "falso", ou radical x neoliberal, ou OPs ascendentes $x$ descendentes) não consegue captar a complexidade desse mosaico transnacional. Contudo, algumas questões mais gerais valem ser levantadas. O orçamento participativo e, de forma mais ampla, a participação cidadã se tornarão apenas mais uma "ferramenta" 
de participação na pauta de organizações internacionais e de governos nacionais e locais? Esses mecanismos farão parte de um movimento mais amplo de mudança social e política? Eles, de fato, modificarão as relações entre os cidadãos e o governo municipal, assim como entre este e o governo central? O futuro está aberto, e parece provável que não haverá uma resposta única: os desenvolvimentos subsequentes ainda irão esboçar um complexo mosaico. Eles dependerão dos contextos nacionais e locais, das transferências, da vontade política dos governos nacionais e locais - mas o envolvimento da sociedade civil e dos movimentos sociais de base também será um fator decisivo.

\section{Referências}

ABERS, R. Inventing Local Democracy. Grassroots Politics in Brazil. London: Lynne Rienner Publishers, Boulder. 2000.

ALLEGRETTI, G. L'insegnamento di Porto Alegre. Autoprogettualità come paradigma urbano. Alinea, Firenze. 2003.

AVRITZER, L. Democracy and the Public Space in Latin America. Princeton: University Press Princeton. 2002.

AVRITZER, L Participatory Institutions in Democratic Brazil. Baltimore: The John Hopkins University Press. 2009.

BAIERLE, S. Urban Struggles in Porto Alegre: between Political Revolution and Transformism. Porto Alegre: ONG Cidade. 2007.

BAIOCCHI, G. Militants and Citizens. The Politics of Participatory Democracy in Porto Alegre. Stanford : Stanford University Press. 2005.

BOHMAN, J.; REHG, W. (eds.) Deliberative Democracy. Cambridge: MIT Press, MA. 1997.

CABANNES, Y. (ed.) Participatory budgeting and Local Finances. Network Urbal European Community e UMP-LAC, Porto Alegre, n.9, 2003.

CABANNES, Y. Answers to $\mathbf{7 2}$ Frequently Asked Questions About Participatory Budgeting. UMP-LAC, UN-HABITAT and UNDP, Quito. 2004. Disponível em: www.unhabitat.org/documents/faqqPP.pdf.

CHAUDHURIS, S.; HELLER, P. The plasticity of participation: evidence from a participatory governance experiment. 2002. Disponível em: www.siteresources. 
worldbank.org/INTEMPOWERMENT/Resources/ 13892_chaudhuri_heller.pdf>, acessado em 24 de Novembro de 2009.

CO-PLAN (ed.). Participatory Budgeting Pilot in Elbasan Municipality. Co-Plan, Tirana. 2005. Disponível em: www.co-plan.org.

CO-PLAN (ed.) A Brief Summary of the Participatory Budgeting Process in the Municipality of Fier. Co-Plan, Tirana. 2007. Disponível em: www.co-plan.org.

DAlTON R.; WATTENBerG, M. (dir.) Parties without Partisans: Political Changes in Advanced Industrial Societies. Oxford: Oxford University Press. 2002.

ESPING-ANDERSEN. The Three Worlds of Welfare Capitalism. Princeton: Princeton University Press. 1990.

FEDOZZI, L. Orçamento participativo: Reflexões sobre a experiência de Porto Alegre.. Tomo, Porto Alegre. 1999.

FEDOZZI, L. O Poder da aldeia. Porto Alegre, Tomo. 2000.

FEDOZZI, L. Observando o Orçamento participativo de Porto Alegre. Porto Alegre: Tomo. 2007.

FISHKIN, J. The Voice of the People. Public Opinion \& Democracy. London : Yale University Press, New Haven.. 1998.

FONT J. (ed.) Ciudadanos y decisiones públicas. Barcelona : Ariel. 2001.

FUNG, A.; WRIGHT, E. O. (eds.) Deepening Democracy: Institutional Innovations in Empowered Participatory Governance. Verso, London/New York. 2003.

GANUZA, E. Tipologia y Modelos de los Presupuestos Participativos en España. Cordoba: Working Paper. IESA. 2007.

GENRO, T.; de SOUZA, U. Orçamento Participativo. A experiência de Porto Alegre. São Paulo: Editora Fundação Perseu Abramo. 1997.

GRAZIA DE GRAZIA, A.C.; Torres R. Experiências de Orçamento Participativo no Brasil. Porto Alegre : Vozes. 2003.

GRET, M.; SINTOMER, Y. The Porto Alegre Experiment: Learning Lessons for a Better Democracy. London : Zed-Books. 2005.

GUEYE, B. Le budget participatif en pratique. IED-Afrique, Dakar. 2008.

HE, B. Chinese approaches in participatory budgeting: The experience of Zeguo. 2012. In SINTOMER et al. 2012 b.

HERZBERG, C. Der Bürgerhaushalt von Porto Alegre. Lit, Münster. 2001.

JAIN, L.C. Decentralisation and local governance. Orient Longma, New Delhi. 2005. 
KANOUTE, M. B. Manuel du budget participatif en Afrique Francophone.ONU HABITAT and ENDA TM (eds.), Dakar. 2007. Disponível em: www.unhabitat.org. KIM, K; KIM, O. Impact Analysis on Citizen Participation Performance. In the Government Budgeting Process. The Korean Journal of Local Government Studies v. 2, n.11, p.87-107 (em coreano). 2007.

KWACK, C.G. Basic Model and Design Alternatives of Participatory Budgeting. The Korea Local Finance Journal. v.10, n.1, p.247-276 (em coreano). 2005.

LEIB E.J.; HE, B. (eds.) The Search for Deliberative Democracy in China. PalgraveMacMillan, Houndmills. 2005.

LERNER, J.; WAGNER, E. Van Participatory Budgeting in Canada: Democratic Innovations in Strategic Spaces. TNI, Amsterdam. 2006. Disponível em: www.tni.org. LIU, P.; TRAUB-MERZ, R. (eds.) Public Participation in Local Decision-Making: China and Germany. Shanghai: Academy of Social Sciences Press Shanghai. 2009.

MARQUETTI, A. Characteristics of Brazilian Cities Experimenting with participatory Budgeting. Working Paper. Porto Alegre: PUCRS. 2005.

MARQUETTI, A.; DE CAMPOS, G.; PIRES, R. (eds.) Democracia Participativa e Redistribuição: Análise de Experiências de Orçamento Participativo. São Paulo: Xamã. 2008.

MATSUBARA, A. Participatory Budgeting in Japan: the case of the City of Ichikawa. 2012. In: SINTOMER et al. 2012b.

MORORÓ R.R. Participatory Budgets as a Mean of Promoting More Equitable Distribution of Public resources: Potential and Contradictions, paper presented. At the Conference "Beyond Accra: Practical Implications of Ownership and Accountability in national Development Strategies". London: 2009.

NEUNECKER, N.; MASTUTI, S. S. Indonesia: Engendering Participatory Budgeting to Reach Poor People: Tanah Datar - Indonesia Experience. 2012. In: SINTOMER et al. 2012.

OLOWU, D. Local Democracy, Taxation and Multi-level Governance in Africa. The Hague: Institute of Social Studies. 2003.

RAZA, A.; WEISER, E.T. Fostering Participatory Budgeting. Manila: Asian Development Bank and The Asia Foundation. 2006.

RONG, H. Public Participation in Decision-making: Transport Administration and Bus Line Planning. 2009. In: LIU, P. e TRAUB-MERZ. 2009.

SANTOS, B. de Sousa Participatory Budgeting in Porto Alegre: Toward a Redistributive Democracy. Politics \& Society. v. 26, n.4, p. 461-510. 1998. 
SHAH, A. (ed.) Participatory Budgeting. Washington: World Bank Publications. 2007.

SINTOMER, Y.; HERZBERG, C.; RÖCKE, A. Participatory budgeting in Europe: potentials and challenges. International Journal of Urban and Regional Research. v.32, n.1, p.164-178. 2008.

SINTOMER, Y. et all Learning from the South: Participatory Budgeting Worldwide - an Invitation to Global Cooperation. GIZ, Bonn. 2010. Disponível em: www.service-eine-welt.de/

SINTOMER, Y.; HERZBERG, C.; RÖCKE, A. Participatory Democracy and Public Service Modernisation. Ashgate, Farnham. 2012a.

SINTOMER, Y. et all (eds.) Participatory Budgeting in Asia and Europe, Key Challenges of Participation. Palgrave Macmillan Houdmills. 2012b.

SMITH G. Democratic Innovations: Designing Institutions for Citizen Participation (Theories of Institutional Design). Cambridge: Cambridge University Press. 2009.

SONGMIN, A. Participatory Budgeting in Korea: the case of Dong-Ku, Ulsan. 2012. In: Sintomer et all. 2012b.

SMOKE, P. Local Revenues under Fiscal Decentralization in Developing Countries: Linking Policy Reform, Governance and Capacity. Cambridge: Lincoln Institute, MA. 2007.

TALPIN, J. Schools of Democracy. How Ordinary Citizens (Sometimes) Become More Competent in Participatory Budgeting Institutions. Colchester: ECPR Press. 2011,

TOCAL, M.; MONTERO, J. R. (eds.) Political Disaffection in Contemporary Democracies. Social Capital, Institutions, and Politics. Routledge, London/New York. (2006) UCLG (ed.) Decentralization and Local Democracy in the World: First Global Report. Barcelona: UCLG. 2008.

UN-HABITAT e MDP (eds.) Participatory Budgeting in Africa: A Training Companion. UN-Habitat/MDP, Nairobi/Harare. 2008.

WORLD BANK (ed.) Brazil Toward a More Inclusive and Effective Participatory Budget in Porto Alegre. Washington: World Bank. 2008.

ZAMBONI, Y. Participatory Budgeting and Local Governance: An Evidence-Based Evaluation of Participatory Budgeting Experiences in Brazil. Working Paper. Brasília: Controladoria Geral da União. 2007. Disponível em: www.bvc.cgu.gov.br.

Recebido em: 12/12/2011

Aceite final: 06/01/2012 
